\title{
THE ROLE OF ORGANIZATIONAL SUPPORTING IN MODERATING THE WHISTLEBLOWING BEHAVIOR INTENTION
}

\author{
Azwar Iskandar ${ }^{1}$, Ita Hartati ${ }^{2}$ \\ ${ }^{1}$ Master Program in Public Administration, Universitas Terbuka, Indonesia \\ ${ }^{2}$ Pusdiklat Pengembangan Sumber Daya Manusia, BPPK, Kementerian Keuangan \\ e-mail: azwar.iskandar@gmail.com
}

\begin{abstract}
This study aimed to analyze the influence of the attitude toward behaviour and perceived behavioural control on whistleblowing intention, and the role of organizational supporting of employees as moderating variable in the influence of the attitude toward behaviour and perceived behavioural control on whistleblowing intention of employees. This study used primary data from a questionnaire, simple random sampling method and quantitative approach of Moderate Regression Analysis (MRA) technique. This study empirically showed that the implementation of the whistleblowing system has not been successful. Based on the three hypotheses proposed, all of them were not proven and accepted. The attitude toward behaviour has no significant effect on whistleblowing intention by the employees. The perceived behavioural control had a significant effect on whistleblowing intention by employees. In other that, the current organizational support of employees can not play a role as moderation influencing attitudes and perceived behavioural control over internal whistleblowing intention. The government needs to create special laws and rules to give enough law protection for the whistleblower in the public sector.
\end{abstract}

Keywords: whistleblowing; attitude; perceived; organizational supporting; moderating

\section{INTRODUCTION}

One of the targets of bureaucratic reform programs in the public sector is the improvement of services throughout the service activities of existing work units. The Ministry of Finance as one of the units or state institutions in charge of organizing government affairs in the field of state finance, has started and implemented this program since more than ten years ago. One of the products of bureaucratic reform programs that have been encouraged within the Ministry of Finance is the launch of a whistleblowing system. This product begins with the issuance of Regulation of the Minister of Finance Number 103/PMK.09/2010 concerning Procedures for Management and Follow-up Reporting at the Ministry of Finance, which was then followed by the issuance of technical guidelines for reporting violations in the form of Decree of the Minister of Finance Number 149/KMK.09/2011 on Procedures for Management and Follow-up of Violation Reporting (Whistleblowing) and Procedures for Reporting and Publication of The Implementation of Whistleblowing in the Ministry of Finance. Complaint service through whistleblowing is a web-based service as a form of development in the complaints service system that was originally carried out conventionally by mail, telephone, SMS or facsimile.

In general, whistleblowing is the disclosure of violations or disclosures of unlawful acts, unethical/immoral acts or other acts that may harm the organization or stakeholders. Such actions may be taken by employees or leaders of organizations to the leaders of other organizations or institutions that can take action for such violations. Such disclosures are generally made confidentially. While the whistleblower is an employee in an organization that conducts whistleblowing by witnessing, knowing, and reporting any crime or practice that is investigating and threatening the public interest in his organization and decided to disclose the irregularities to the public or authorized agencies. Whistleblowing can also be interpreted as an act of disclosing information from a private or public organization to open dangerous corruption cases to the public (Kumar \& Santoro, 2017).

Jeon (2017) revealed that whistleblowers play an important role in opening up unethical behavior in the government and making the government more transparent and accountable to 
the public. Furthermore, Sweeney (2008) stated that whistleblowing is more effectively applied to combat fraud than internal audit, external audit, or internal controlling system.

Being a whistleblower is basically not an easy thing. A person from an internal organization will generally face the dilemma of deciding whether to "blow the whistle" or let it stay stunned. Some view whistleblowers as traitors who violate organizational loyalty norms, others view whistleblowers as heroic protectors of values that are considered more important than loyalty to the organization. Such conflicting views often put would-be whistleblowers in the dilemma of determining attitudes that could ultimately distort whistleblowing intention. A survey conducted by Park \& Blenkinsopp (2009) on several companies implementing a complaints system, states that only $32 \%$ of complaint systems can run effectively.

Some whistleblowing experts and practitioners have applied the concept of Theory of Planned Behavior (TPB) to measure one's intention to become a whistleblower. This theory explains that behaviors carried out by individuals arise due to the intention to behave formed from attitude toward behavior, subjective norms, and perceived behavioral control owned by individuals (Ajzen, 2012).

Some previous studies have given inconsistent results and seemed to vary (contradictory) regarding the application of this TPB concept. This indicates that there is a research gap that allows it to be filled. The research was conducted by Uddin \& Gillett (2005) which gave the results of subjective norms negatively affect the intention of financial managers in conducting the presentation of financial statements. The results of a different study obtained by Carpenter \& Reimers (2005) which showed empirical evidence of subjective norms positively influenced the intention of financial managers in conducting fraudulent presentation of financial statements. Therefore, it is interesting to conduct studies and analysis related to whistleblowing behavior, especially in the public sector.

This research was carried out with the general purpose of looking at the implementation of whistleblowing in public organization, especially in the Ministry of Finance based on the concept of TPB. While the specific purpose of the research in detail is to analyze the influence of attitude toward behavior and perceived behavioral control on the whistleblowing intention and the role of organizational supporting of employees as a mediator of the influence of attitude toward behavior and perceived behavioral control on the whistleblowing intention.

This research is different from previous research conducted by Banda (2012), Bagustianto \& Nurkholis (2015), and Lestari \& Yaya (2017) because the object of this research is employees who have a working period of under five years, while in the previous research using research objects Civil Servants (PNS) or auditors who have long worked. The selection of the object of this research is based on the reason that the relatively new employee status in the organization is expected to be a driver for employees to have the courage to become a whistleblower or whistleblower because they relatively do not have various opportunities that can prevent him from becoming a whistleblower.

In addition, this study does not fully apply the concept or model of TPB by Ajzen (1991) as in previous studies. In this study, researchers also combined or used research frameworks or models created by Latan, Ringle and Jabbour (2016). In this model, the relationship path or influence of attitude toward behavior and perceived behavioral control to whistleblowing intention variables are moderated by organizational supporting as moderating variable. This variable was chosen as a moderator variable because in research conducted by Alleyne, Hudaib and Haniffa (2015), Latan, Ringle and Jabbour (2016), and Yuswono and Hartijasti (2018), this variable was empirically proven to moderate the influence of attitudes and perceptions of behavioral control on the intention to whistleblowing. The results of this study are expected to provide valuable inputs or recommendations for efforts to improve the concept and application of whistleblowing system that is being applied today.

\section{Literature Review And Hypothesis Development}

Some whistleblowing experts and practitioners have applied the concept of Theory of Planned Behavior (TPB) to measure a person's intention to become a whistleblower (Figure 1). This theory explains that behaviors carried out by individuals arise due to the intention to behave. Based on this theory, it can be known that intention are formed from attitude toward behavior, subjective norms, and perceived behavioral control owned by individuals. Attitude 
toward behavior is a positive or negative evaluation of certain objects, people, institutions, events, behaviors or intention (Ajzen, 2012).

An individual's attitude to a behavior is derived from a belief in the consequences that such behavior has. If a person performs behaviors that produce positive outcomes, then the individual has a positive attitude, and vice versa. Subjective norm is a factor outside the individual that indicates a person's perception of the behavior being carried out. Subjective norms are not only determined referent, but also motivation to comply. If the individual believes that the referent approves of himself/her to carry out a behavior and is motivated to follow a behavior, then the individual will feel a social pressure to do so, and vice versa (Ajzen, 2012). Perceived behavioral control is an individual's perception or self-ability regarding the individual's control over a behavior. Perceived behavioral control is determined by an individual's past experiences or influenced by the experiences of others. The individual will perform a behavior if it has evaluated the behavior positively, there is social pressure to perform the behavior, as well as the individual believes and has the opportunity to perform a behavior (Ajzen, 2012).

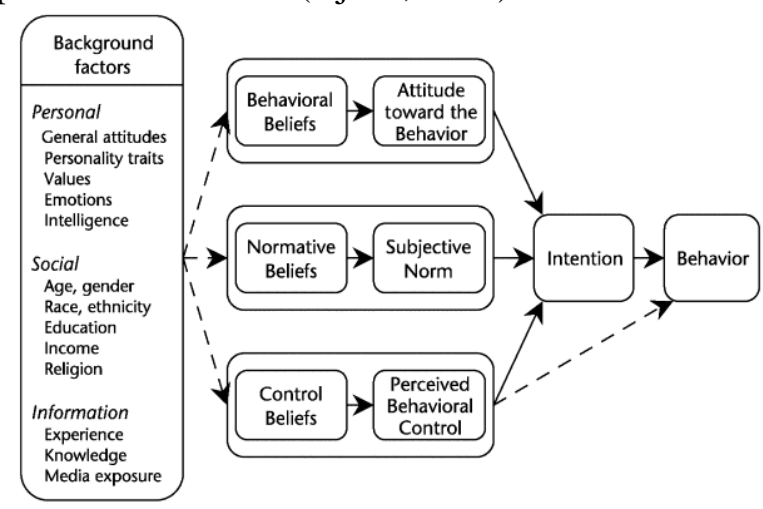

\section{Figure 1 \\ Theory Planned Behavior Model \\ Source: (Ajzen, 1991, 2012)}

Banda's research (2012) which tested TPB on whistleblowing intention in internal auditors of the Audit Board of Finance (BPK) Indonesia found that moral reasoning and perception of control over behavior did not significantly affect the intention to conduct fraud disclosure, while attitudes towards behavior and subjective norms influenced whistleblowing intention. In contrast to Daivitri's research (2013), attitudes towards subjective behavior and norms have a significant effect on the whistlebowing intention of employees of the Center for Reporting and Analysis of Financial Transactions (PPATK), while the perception of control of negative behavior towards the whistleblowing intention of PPATK employees. The application of TPB has been done in various contexts such as tax compliance (Bobek \& Hatfield, 2003; Hidayat \& Nugroho, 2010), public accountant behavior (Buchan, 2005), ethical decisions manajer (Carpenter \& Reimers, 2005), whistleblowing behavior by chief financial officer (Uddin \& Gillett, 2002) and in budget making ( $\mathrm{Su} \& \mathrm{Ni}$, 2013). Previous research that has been done on the behavior of state civil apparatus (ASN) in public sector organizations is research by Rustiarini \& Sunarsih (2015), Bagustianto \& Nurkholis (2015), and Lestari \& Yaya (2017) which examines the behavior of ASN respectively in the CPC, Financial and Development Supervisory Agency (BPKP) and the Ministry of Finance in the Special Region of Yogyakarta.

This research was developed based on the concept approach of TPB that the intention to perform behavior (intention) is a component of the individual's self that refers to the desire to perform certain behaviors. The greater the perceived perception of behavioral control, the stronger a person's intention to perform the behavior is considered. On the other hand, the direct relationship between perceived behavioral control and intention over behavior itself is based on the understanding that the greater a person has the opportunity and how much obstruction can be anticipated, the greater the perceived control over the intention of the behavior (Ajzen, 2012). Furthermore, the existence of a good environment in the form of organizational support is believed to be a good medium in moderating the relationship of influence between attitudes and perceptions of behavioral control over the intention to conduct whistleblowing (Alleyne, Hudaib and Haniffa, 2015; Latan, Ringle and Jabbour, 2016; and Yuswono and Hartijasti, 2018). Therefore, this research formulates several research hypotheses to be tested, namely:

$\mathrm{H}_{1}$ : attitude toward behavior affects employees' whistleblowing intention

$\mathrm{H}_{2}$ : perceived behavioral control affects employees' whistleblowing intention

$\mathrm{H}_{3}$ : organizational support can be a good moderator in the relationship between attitude toward behavoiur and perceived behavioral control to employees' whistleblowing intention 
Based on the description of the literature review, previous research and hypotheses that have been formulated, the frame of thought of this research can be described as follows:

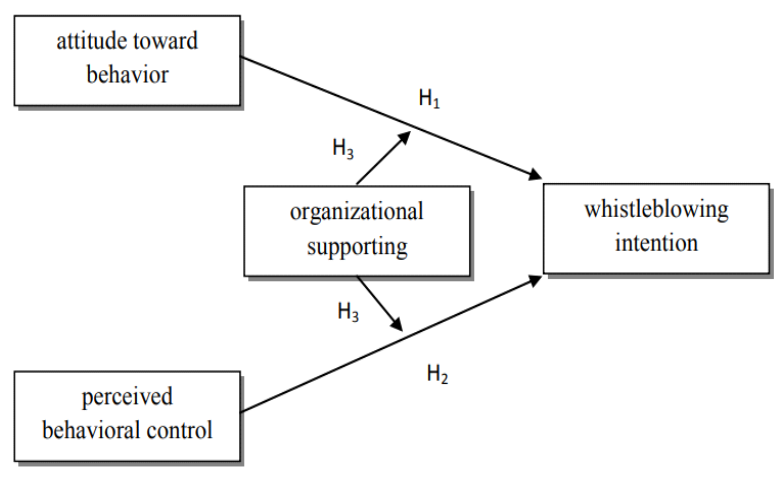

Figure 2

Research Framework

\section{RESEARCH METHOD}

This research is a case study research, namely research on the status of research subjects related to a specific phase or typical of the overall personality (Nazir, 2003). From the problems studied, this research is a causality research that aims to analyze the relationship or influence (causality) of two or more phenomena through hypothesis testing (Sekaran, 2006).

\section{Research Data}

The data used in this study is primary data and secondary data. The primary data was obtained directly from respondents through questionnaires. The distribution of research questionnaires was conducted by online with google forms. Questionnaires were sent online to all respondents through the email address of each responseden. While the secondary data was obtained from several sources such as The Implementation Section of Makassar Financial Training Center, Evaluation and Information Section of Makassar Financial Training Center, Human Resources Development Center (PSDM) of the Financial Education and Training Agency (BPPK), and others.

\section{Population and Sample}

The population in this study are employees who have a working period of under five years. Based on data availability considerations, the population is alumni of basic education and training (Latsar) program period 4 of 2016 and period 1, 2 and 3 of 2017 held at the Makassar
Financial Training Center, which amounts to 398 people. The selected training period is 2016 and 2017, because the new curriculum or training model began to be implemented in 2016 to date. The new model of basic education and training (Latsar) program (in accordance with The Head of State Administration Regulation Number 21 of 2016) combines classical and non-classical learning in the training ground and in the workplace. This enables participants to be able to internalize, absorb, actualize, and explore the values of training materials consisting of accountability, nationalism, public ethics, quality commitment, and anti-corruption as a habituation. The alumni of this latsar come from work units within the Directorate General of Taxation (DJP) and the Directorate General of Customs and Excise (DGCE). In addition to the availability of data, these two Echelon I units were selected because of the high probability or potential for fraud or violations in both units based on the author observations (e.g. in the practice of procurement of goods/services where author had served as a member of the ULP Pokja Ministry of South Sulawesi Province for the period 20142016). Given that the respondent's status is relatively homogeneous, the sampling technique used in this study is simple random sampling. To determine the number of samples, the study used the Slovin formula (Ariola, 2006): $\mathrm{n}=\mathrm{N} /[1+(\mathrm{N}$. $\alpha 2)$ ], where $n=$ number of research samples, $N=$ Number of research population, and $\alpha=$ error level (error rate). By using the Slovin formula and error level of 5\% (significance level), the number of samples of this study was determined as many as 199 people.

\section{Research Variables and Indicators}

This study used four variables from the model issued by Latan, Ringle and Jabbour (2016). These variables consist of independent variables, dependent variables, and moderator variable. The independent variables of this study are attitude toward behavior $\left(\mathrm{X}_{1}\right)$ and perceived behavioral control $\left(\mathrm{X}_{2}\right)$. Dependent variable is the intention to whistleblowing (Y). While the moderator variable is organizational support of employees $\left(X_{3}\right)$. The operational definitions, descriptions and indicators of each of these variables are described in Table 1. Each variable is measured using a 5-point Likert scale, i.e. strongly agree: 5 ; agree: 4 ; disagree: 3 ; disagree: 2 ; strongly disagree: 1 . 


\section{Table 1}

\section{Research Variable}

\begin{tabular}{|c|c|c|c|}
\hline No. & Variable & Description & Indicators \\
\hline 1 & $\begin{array}{l}\text { attitude } \\
\text { toward } \\
\text { behavior } \\
\left(\mathrm{X}_{1}\right)\end{array}$ & $\begin{array}{l}\text { It is a person's } \\
\text { judgment when } \\
\text { looking at or } \\
\text { knowing a } \\
\text { behavior } \\
\text { committed by a } \\
\text { person. The } \\
\text { assessment given } \\
\text { can be either } \\
\text { positive or } \\
\text { negative } \\
\text { (Sulistomo \& } \\
\text { Prastiwi, 2011). }\end{array}$ & $\begin{array}{l}\text { This variable was } \\
\text { measured using } \\
\text { four statement } \\
\text { items adopted } \\
\text { from the research } \\
\text { of Sulistomo and } \\
\text { Prastiwi (2011) } \\
\text { and Hays (2013). }\end{array}$ \\
\hline 2. & $\begin{array}{l}\text { perceived } \\
\text { behavioral } \\
\text { control } \\
\left(\mathrm{X}_{2}\right)\end{array}$ & $\begin{array}{l}\text { It is a person's } \\
\text { perception of a } \\
\text { behavior by } \\
\text { another person, } \\
\text { where he believes } \\
\text { that the } \\
\text { perception he has } \\
\text { is the result of his } \\
\text { own control of the } \\
\text { perception of such } \\
\text { behavior } \\
\text { (Sulistomo and } \\
\text { Prastiwi, 2011). }\end{array}$ & $\begin{array}{l}\text { This variable was } \\
\text { measured using } 3 \\
\text { statement items } \\
\text { adopted from the } \\
\text { research of } \\
\text { Sulistomo and } \\
\text { Prastiwi (2011) } \\
\text { and Hays (2013). }\end{array}$ \\
\hline 3. & $\begin{array}{l}\text { organizati } \\
\text { onal } \\
\text { support } \\
\left(\mathrm{X}_{3}\right)\end{array}$ & $\begin{array}{l}\text { Kurtessis et al. } \\
\text { (2015) explained } \\
\text { that } \\
\text { organizational } \\
\text { support is an } \\
\text { individual's } \\
\text { perception that } \\
\text { organizational and } \\
\text { environmental } \\
\text { support or } \\
\text { influence can } \\
\text { provide positive } \\
\text { or negative } \\
\text { feedback on } \\
\text { behavior. }\end{array}$ & $\begin{array}{l}\text { This variable was } \\
\text { measured using } \\
\text { four statement } \\
\text { items adopted } \\
\text { from the research } \\
\text { of Sulistomo and } \\
\text { Prastiwi (2011) } \\
\text { and Hays (2013). }\end{array}$ \\
\hline 4. & $\begin{array}{l}\text { whistleblo } \\
\text { wing } \\
\text { intention } \\
\text { (Y) }\end{array}$ & $\begin{array}{l}\text { Individual self- } \\
\text { component that } \\
\text { refers to the desire } \\
\text { to perform certain } \\
\text { behaviors } \\
\text { (Parianti, et al., } \\
\text { 2016). }\end{array}$ & $\begin{array}{l}\text { This variable was } \\
\text { measured using } 3 \\
\text { statement items } \\
\text { adopted from } \\
\text { Sulistomo and } \\
\text { Prastiwi research } \\
\text { (2011). }\end{array}$ \\
\hline
\end{tabular}

\section{Analytical Techniques}

Before analyzing the data, data quality test is first carried out. Data quality testing aims to find out if the instrument used is valid and reliable, because the correctness of the processed data is very determined the data quality.

The data quality test used in this study is a test of validity and reliability. A validity test is a measure that indicates the validity of an instrument (Suharsimi, 2006). A questionnaire is said to be valid if the question on the questionnaire is able to reveal something that will be measured by the questionnaire. The significance test is done by comparing the value of $r$ calculate with $r$ table for degree of freedom $(\mathrm{df})=\mathrm{n}-2$, in this case $\mathrm{n}$ is the number of samples. To test whether each indicator is valid or not, it can be seen in the Cronbach Alpha output view in the Correlated Item-Total Correlation column. If r-calculated greater than r-table and a positive value then the item or indicator is valid. While reliability test, according to Ghozali (2006), is a tool to measure a questionnaire that is an indicator of variables or constructs. A questionnaire is said to be reliable if a person's answer to a statement is consistent or stable over time. Reliability measurement in this study using Cronbach Alpha $(\alpha)$ method was measured based on Cronbach Alpha scale $(\alpha) 0$ to 1 . Cronbach Alpha value $>$ 0.5 is categorized as reliable (Triton, 2005).

To test the research hypothesis, a regression coefficient test is conducted to determine whether independent variables have a positive or negative influence on dependent variables. A positive influence is indicated by a postive mark on the regression coefficient. While negative influences are indicated by negative signs of regression coefficients. The statistical t-test (partially), according to Ghozali (2006), basically shows how far the influence of one independent variable individually in explaining dependent variables. For this study, the test was conducted using a significant level of $0.05(\alpha=5 \%)$. Acceptance or rejection of the hypothesis is carried out with the following criteria:

- If the significant value (Sig.) $>0.05$ or $\mathrm{t}$ calculated $<\mathrm{t}$-table (minus value ignored) then the hypothesis is rejected or the regression coefficient is insignificant. This means that partially independent variables do not have a significant influence on dependent variables.

- If the significant value (Sig.) $\leq 0.05$ or tcalculated $>$ t-table (minus value ignored) then the hypothesis is accepted or the regression coefficient is significant. This means that partially these independent variables have a significant influence on dependent variables.

The technique used in data analysis is inferential statistics. In this study, data analysis used multiple linear regression approaches for hypotheses 1 and 2, and multilevel regression for hypothesis 3. There are three ways to test regression with moderating variables, namely: (1) Interaction Test, (2) Absolute Difference Value 
Test and (3) Residual Test. In this study, the technique used was Interaction Test. Interaction test or often referred to as Moderate Regression Analysis (MRA) is a special application of multiple linear regression where in the regression equation contains elements of interaction (multiplication of two or more independent variables) (Ghazali, 2005).

Based on the proposed hypothesis, the structural model of multiple linear regression analysis in this study can be formulated as follows:

Model I:

$\mathrm{Y}={ }_{\rho} \mathrm{X}_{1}+{ }_{\rho} \mathrm{X}_{2}+\mathrm{e}$;

\section{Model II:}

(1) $Y={ }_{\rho} X_{1}+{ }_{\rho} X_{2}+{ }_{\rho} X_{3}+e$

(2) $Y={ }_{\rho} X_{1}+{ }_{\rho} X_{2}+{ }_{\rho} X_{3}+{ }_{\rho} X_{1} \cdot X_{3}+{ }_{\rho} X_{2} \cdot X_{3}+e$

where $\mathrm{X} 1=$ attitude toward behavior, $\mathrm{X} 2=$ perceived behavioral control, $\mathrm{X} 3=$ organizational support, $\mathrm{Y}=$ whistleblowing intention, and $\rho=$ regression coefficient, and $\mathrm{e}=$ error value .

\section{RESULTS AND DISCUSSIONS}

The number of respondents assigned as sample of this study amounted to 199 people. Research questionnaires have been sent by online to all respondents via email using the Google Forms. Until the deadline for returning the questionnaire, there were 14 failed notifications sent from google system because the existing email address turned out to be invalid. That is, there were 14 respondents who were declared dead as a sample. Meanwhile, the number of respondents who returned the questionnaire in a fully filled state was only 81 people. This means that the response rate only reaches $43.78 \%$ of the number of valid samples set. Although the response rate does not reach $100 \%$, research can still be continued to the analysis stage. Hartono (2011) stated that the response rate does not have to reach $100 \%$, but will be better if the response rate is higher. Even questionnaires sent by medium (such as postal or e-mail) with a response rate of $30 \%$ can be said to be adequate. The filled questionnaire was then tabulated, followed by the description and classification of respondents based on gender, experience and education and data processing.

\section{Validity and Realibility Test}

According to Ghozali (2006), validity test is used to measure the validity of a questionnaire. A questionnaire is said to be valid if the question on the questionnaire is able to reveal something that will be measured by the questionnaire. The significance test is done by comparing the value of r-calculated with r-table for degree of freedom $(d f)=\mathrm{n}-2$, in this case $n$ is the number of samples. To test whether each indicator is valid or not, it can be seen in the Cronbach Alpha output view in the Correlated Item-Total Correlation (r) column. If $\mathrm{r}$-calculated greater than $\mathrm{r}$-table and values are positive then the item or question or indicator is declared valid (Ghozali, 2006).

Table 2

Results of Validity Test

\begin{tabular}{|c|c|c|c|}
\hline Variable & $\begin{array}{l}\text { Question } \\
\text { Item }\end{array}$ & $\begin{array}{c}\text { Corrected } \\
\text { Item-Total } \\
\text { Correlation }\end{array}$ & Status \\
\hline \multirow{4}{*}{$\begin{array}{c}\text { attitude toward } \\
\text { behavior } \\
\left(\mathrm{X}_{1}\right)\end{array}$} & 1 & $.635 * *$ & Valid \\
\hline & 2 & $.781 * *$ & Valid \\
\hline & 3 & $.828 * *$ & Valid \\
\hline & 4 & $.732 * *$ & Valid \\
\hline \multirow{3}{*}{$\begin{array}{l}\text { perceived } \\
\text { behavioral } \\
\text { control } \\
\left(\mathrm{X}_{2}\right)\end{array}$} & 1 & $.781 * *$ & Valid \\
\hline & 2 & $.756^{* *}$ & Valid \\
\hline & 3 & $.758 * *$ & Valid \\
\hline \multirow{4}{*}{$\begin{array}{l}\text { organizational } \\
\text { supporting } \\
\left(\mathrm{X}_{3}\right)\end{array}$} & 1 & $.813 * *$ & Valid \\
\hline & 2 & $.841 * *$ & Valid \\
\hline & 3 & $.886^{* *}$ & Valid \\
\hline & 4 & $.718 * *$ & Valid \\
\hline \multirow{3}{*}{$\begin{array}{l}\text { whistleblowing } \\
\text { intention } \\
\text { (Y) }\end{array}$} & 1 & $.953 * *$ & Valid \\
\hline & 2 & $.930 * *$ & Valid \\
\hline & 3 & $.914 * *$ & Valid \\
\hline
\end{tabular}

$* *$. Correlation is significant at the 0.01 level (2-tailed). Source: Author's Calculation

Based on validity test results in Table 2, by comparing each r-calculated value (Correlation Item-Total Correlation) on each question item with r-table for degree of freedom $(\mathrm{df})=\mathrm{n}-2$, where $\mathrm{r}$-table $=0.2185$, it was found that all r-calculated of each question used as an instrument to measure research vaiabel is greater than the value of $r$ table. So it can be stated that the research instrument for measuring all the variables in this study is valid.

While reliability, according to Ghozali (2006), is a tool to measure the reliability of a questionnaire that is an indicator of variables 
or constructs. A questionnaire is said to be reliable or reliable if a person's answer to a statement is consistent or stable over time. The realibility test used in this study was the Cronbach Aplha test. A construct or variable is declared reliabel if it gives a Cronbach Alpha value > 0.60 (Ghozali, 2006).

Table 3

\begin{tabular}{|c|c|c|}
\hline \multicolumn{3}{|c|}{ Results of Validity Test } \\
\hline Variable & $\begin{array}{c}\text { Cronbach's } \\
\text { Alpha }\end{array}$ & Status \\
\hline $\begin{array}{l}\text { attitude toward } \\
\text { behavior }\left(\mathrm{X}_{1}\right)\end{array}$ & 0.713 & Reliable \\
\hline $\begin{array}{l}\text { perceived behavioral } \\
\text { control }\left(\mathrm{X}_{2}\right)\end{array}$ & 0.625 & Reliable \\
\hline $\begin{array}{c}\text { organizational } \\
\text { supporting }\left(\mathrm{X}_{3}\right)\end{array}$ & 0.820 & Reliable \\
\hline $\begin{array}{l}\text { whistleblowing } \\
\text { intention }(\mathrm{Y})\end{array}$ & 0.925 & Reliable \\
\hline
\end{tabular}

Source: Author's Calculation

Validity Test results against the research data, by comparing each of Cronbach's Alpha values on each variable or research instrument, found a value greater than 0.6 , so it can be stated that the research instrument for measuring variables in this study is reliable (Table 3).

\section{Regression Results}

\section{Table 4}

\section{Result of Regression Model I}

\begin{tabular}{lccc}
\hline \multicolumn{1}{c}{ Variabel } & $\begin{array}{c}\text { Standardized } \\
\text { Coefficients }\end{array}$ & $\mathbf{t}$ & Sig. \\
\hline Constant & 2.226 & 1.714 & 0.090 \\
\hline $\begin{array}{l}\text { attitude toward } \\
\text { behavior }\left(\mathrm{X}_{1}\right)\end{array}$ & 0.168 & 1.710 & 0.091 \\
\hline $\begin{array}{l}\text { perceived } \\
\text { behavioral } \\
\text { control }\left(\mathrm{X}_{2}\right)\end{array}$ & 0.561 & 5.713 & 0.000 \\
\hline R Square & 0.673 & & \\
\hline $\begin{array}{l}\text { Adjusted R } \\
\text { Square }\end{array}$ & 0.440 & & \\
\hline F-stat. & 35.111 & & \\
\hline Sig. F & 0.000 & & \\
\hline Source: Auth & & & \\
\hline
\end{tabular}

Source: Author's Calculation

From Table 4 is obtained a model of multiple regression equations for Model I, where the value of the regression coefficient is taken from standardized coefficient as follows:

$$
\mathrm{Y}=2,226+0.0168 \mathrm{X}_{1}+0.561 \mathrm{X}_{2}
$$

From the linear regression equation, it can be seen that the number of constants is 2,226, meaning that assuming if the independent variable is zero then the whistleblowing intention is 2,226. Meanwhile, attitude toward behavior $\left(\mathrm{X}_{1}\right)$ was obtained by 0.0168 and perceived behavioral control $\left(\mathrm{X}_{2}\right)$ coefficient was obtained by 0.561 . This means that if $\mathrm{X} 1$ rises by one percent then the whistleblowing intention also rises by 0.0168 when perceived behavioral control variables are considered constant. If the $\mathrm{X}_{2}$ variable rises by one percent then the whistleblowing intention will increase by 0.561 if the attitude towards behavior is considered constant. From the regression equation mentioned above, it can be seen that attitude towards behavior has a positive direction/influence on whistleblowing intention and perceived behavioral control also has a positive direction/influence on the whistleblowing intention.

For hypothesis testing, attitude towards behavior $\left(\mathrm{X}_{1}\right)$ were shown to have an unencable influence on whistleblowing intention $(\mathrm{Y})$. This is based on the value of significance on path of $\mathrm{X}_{1} \mathrm{Y}$ of 0.091 which is greater than $\alpha=0.05$. With this proof, it can be stated that $\mathrm{H} 1$ was rejected. Meanwhile, perceived behavioral control $\left(\mathrm{X}_{2}\right)$ variables proved to have a significant influence on whistleblowing intention (Y). This is based on the value of significance on path of $\mathrm{X}_{2} \quad \mathrm{Y}$ of 0.000 which is lower than $\alpha=0.05$. With this proof, it can be stated that $\mathrm{H}_{2}$ is accepted.

From Table 5 is obtained a model of multiple regression equations for Model II, where the value of regression coefficient is taken from standardized coefficient as follows:

$$
\begin{gathered}
Y=-2.057-0.518 X_{1}+1.092 X_{2}+0.745 X_{3}+ \\
1.426 X 1 . X_{3}-1,943 X_{2} . X_{3}
\end{gathered}
$$

The linear regression equation shows constant 44,040, meaning that assuming an independent variable is zero then the whistleblowing intention is at $-2,057$. Meanwhile, the coefficient of variable $X_{1}$ is obtained by 0.518 , the coefficient of variable $X_{2}$ is obtained by 1,092 , the coefficient of variable $X_{3}$ is obtained by 0.745 , variable $X_{1} . X_{3}$ and $X_{2} . X_{3}$ was obtained by 1,426 and $-1,943$, respectively. From the regression equation above, it can be seen that attitude towards behavior has a negative direction towards whistleblowing intention, perceived behavioral control has a positive direction towards whistleblowing intention, and organizational 
support variable has a positive direction towards whistleblowing intention.

\section{Table 5}

\section{Result of Regression Model II}

\begin{tabular}{|c|c|c|c|}
\hline Variable & $\begin{array}{c}\text { Standardized } \\
\text { Coefficients }\end{array}$ & $\mathbf{t}$ & Sig. \\
\hline \multicolumn{4}{|l|}{ Equation 1: } \\
\hline Constant & 0.937 & .611 & 0.543 \\
\hline $\begin{array}{l}\text { attitude toward } \\
\text { behavior }\left(\mathrm{X}_{1}\right)\end{array}$ & 0.143 & 1.549 & 0.125 \\
\hline $\begin{array}{l}\text { perceived } \\
\text { behavioral } \\
\text { control }\left(\mathrm{X}_{2}\right)\end{array}$ & 0.125 & 1.237 & 0.220 \\
\hline $\begin{array}{l}\text { organizational } \\
\text { supporting }\left(\mathrm{X}_{3}\right)\end{array}$ & 0.523 & 5.193 & 0.000 \\
\hline R Square & 0.468 & & \\
\hline $\begin{array}{l}\text { Adjusted R } \\
\text { Square }\end{array}$ & 0.449 & & \\
\hline $\mathrm{F}$ & 24.593 & & \\
\hline Sig. F & 0.000 & & \\
\hline \multicolumn{4}{|l|}{ Equation 2: } \\
\hline Constant & -2.057 & -0.240 & 0.811 \\
\hline $\begin{array}{l}\text { attitude toward } \\
\text { behavior }\left(\mathrm{X}_{1}\right)\end{array}$ & -0.518 & -1.106 & 0.272 \\
\hline $\begin{array}{l}\text { perceived } \\
\text { behavioral } \\
\text { control }\left(\mathrm{X}_{2}\right)\end{array}$ & 1.092 & 2.522 & 0.014 \\
\hline $\begin{array}{l}\text { organizational } \\
\text { supporting }\left(\mathrm{X}_{3}\right)\end{array}$ & 0.745 & 1.122 & 0.265 \\
\hline $\begin{array}{l}\text { Moderate } 1 \\
\left(\mathrm{X}_{1} \cdot \mathrm{X}_{3}\right)\end{array}$ & 1.426 & 1.512 & 0.134 \\
\hline $\begin{array}{l}\text { Moderate } 2 \\
\left(X_{2} \cdot X_{3}\right)\end{array}$ & -1.943 & -2.296 & 0.024 \\
\hline R Square & 0.503 & & \\
\hline $\begin{array}{l}\text { Adjusted R } \\
\text { Square }\end{array}$ & 0.473 & & \\
\hline $\mathrm{F}$ & 16.589 & & \\
\hline Sig. F & 0.000 & & \\
\hline
\end{tabular}

Source: Author's Calculation

For research hypothesis testing, Moderate 1 variable $\left(\mathrm{X}_{1}, \mathrm{X}_{3}\right)$ proved to have an insentable influence on the variable intention of whistleblowing $(\mathrm{Y})$. This is based on the value of significance on the path of $\mathrm{X}_{1} . \mathrm{X}_{3} \mathrm{Y}$ of 0.134 , greater than $\alpha=0.05$. Meanwhile, Moderate 2 variable $\left(\mathrm{X}_{2} . \mathrm{X}_{3}\right)$ proved to have a siginificant influence on the intention to whistleblowing $(\mathrm{Y})$. This is based on the value of significance on the $\mathrm{X}_{2} . \mathrm{X}_{3} \mathrm{Y}$ of 0.024 which is less than $\alpha=0.05$. Thus, it can be stated that $\mathrm{H}_{3}$ is rejected. This is because the significance value of the entire path influences the moderate variable $\left\{\left(\mathrm{X}_{1}, \mathrm{X}_{3}\right)\right.$ and $\left.\left(X_{2} . X_{3}\right)\right\}$ only one has a significance value below 0.05 . A variable is categorized as a good moderating variable if its interaction between independent variables shows significant value.

\section{Discussion}

The results of the first hypothesis test $\left(\mathrm{H}_{1}\right)$ showed that attitude toward behavior proved to have an insentable influence on the whistleblowing intention. The coefficient of the path marked positive actually indicates a positive influence. The higher the level of positive attitude of employees towards whistleblowing (characterized by indications that respondents consider the thing to be done, is an ethical, hollow and positive action) the higher their intention to whistleblowing. It is as described in the TPB concept that an individual will do something according to his beliefs and beliefs that are considered positive that will be indicated by the intention of the individual. However, this positive attitude has no meaningful effect on their intention to disclose or report any abuse that occurs in the office environment where they currently work.

One of the underlying reasons is that a whistleblower especially in the public environment today does not yet have full confidence in the security and protection of the law when uncovering and reporting fraud or existing violations. This was reinforced by respondents' answers to open questions that expressed hope that relevant agencies could provide certainty over legal protections for those reporting on workplace actions. In line with the results of Rustiarini \& Sunarsih research (2015), employees' positive attitude to reveal cheating is not able to foster strong employee intention to whistleblowing because of these obstacles. The results of this study do not support the results of previous research conducted by Uddin \& Gillett (2002; 2005), Carpenter \& Reimers (2005), and Hays (2013). The difference between the results of this research and previous research may be due to differences in the character of research objects, namely Indonesia and outside Indonesia, where legal certainty in Indonesia, is different from other countries.

These findings, especially from qualitative data collectors through questionnare, are actually important to get attention and ask for further exploration. Nixson et al. (2013) in his research mentioned that in Indonesia there are no regulations specifically governing whistleblowers and justice collaborators. Although explicitly the rules on the protection of whistleblower and justice collaborator laws have been contained in Article 10 of Law Number 13 of 2006 on the Institution of Witness and Victim Protection and 
The Supreme Court Circular Number 4 year 2011 on the Treatment of Whistleblowers and witnesses of cooperating perpetrators (justice collaborator), but these two rules have not been able to protect the existence of whistleblowers and justice collaborators strongly. The current practice of whistleblowing system is only binding in and there is no legal umbrella that can be used as a legal basis for law enforcement officials to be able to protect whistleblowers and justice collaborators in the judicial process. Based on this, law enforcement officers are aware of the importance of the role of whistleblowers and justice collaborators in uncovering corruption cases (Nixson, et al., 2013).

Furthermore, the results of the second hypothesis test $\left(\mathrm{H}_{2}\right)$ showed that perceived behavioral control variables were shown to have a significant influence on whistleblowing intention. The coefficient of positive pathways indicates a positive influence that the higher the level of perception of control over perceived behavior, (characterized by attitudes that ignore perceptions or opinions of others, conduct behavior consciously and above personal control, and feel ready and responsible to accept risk) the stronger the intention of employees to whistleblowing. The results of this study support previous research conducted by Hays (2013), but inconsistent with the results of Carpenter \& Reimers research (2005) which showed that perceived behavior control has no effect on managers' intention to cheat in the presentation of financial statements.

Although still relatively new in the realm of bureaucracy, the employees in this research proved able to build confidence and responsibility to be part of efforts to create good governance. This is understandable because their existence has relatively no vested interests that could preclude him from becoming a whistleblower. In addition, the understanding and internalization of defense materials (especially anti-corruption materials) in Basic Education and Training (Latsar) that they have obtained, is considered capable of fostering their positive attitude in whistleblowing.

The third hypothesis $\left(\mathrm{H}_{3}\right)$ test of the study showed that moderation variables, both on lines 1 and 2, were shown to have an incognito influence on whistleblowing intention. This means that the existence of organizational support that exists today can not be a good moderator in the relationship between attitude toward behaviour and perceived behavioral control to whistleblowing intention. The coefficient of positive value pathways actually shows that the higher the level of organizational support gained from the support of those around them such as superiors, co-workers, and people in general, the higher their intention to whistlebolwing. As explained in the theory that a person's positive perception of a behavior will make the person have the intention to show such behavior. However, the organization's support has not fully exerted any meaningful influence on their intention to disclose or report any abuse that occurred in the office environment where they currently work. These results are not in line with the research results of Alleyne, Hudaib and Haniffa (2015), Latan, Ringle and Jabbour (2016), and Yuswono and Hartijasti (2018).

\section{CONCLUSION}

Based on the results of the analysis and hypothesis testing, it was concluded that whistleblowing implementation for employees in the Ministry of Finance (especially in the research sample) proved empirically has not fully run well and successfully. The three hypotheses proposed are not entirely proven and acceptable. Attitude towards behavior proved to have an insignificant influence to whistleblowing intention. Perceived behavioral control has proven to have a significant influence on whistleblowing intention. In addition, organizational support that exists today can not be a good moderator in the relationship between attitude toward and perceived behavioral control to the whistleblowing intention

\section{Recommendations and Limitations}

Policy recommendations that can be submitted based on these results are that the government needs to develop regulation that specifically regulates the protection of whistleblower, especially employees or the State Civil Apparatus (ASN). The regulation must be integrated and binding on all relevant law enforcement officers so that in handling whistleblower-related cases, law enforcement officials have an agreement to provide protection against the presence of whistleblowers. In addition, strengthening the coaching and mentoring process of superiors and seniors as a form of organizational and environmental support, as well as the commitment of the leadership of the organization, is expected to continue to be pursued to support whistleblowing behavior. 
This research has limitations on the relatively small scope, so the results of the study can not be used as a result of evaluation in general. Further research is recommended to expand the object and subject of the research so that the evaluation of the implementation of whistleblowing can be more measured and comprehensive. In addition, the research method uses data collection techniques through online questionnaires conducted without any assistance and gives full confidence to respondents to fill them out. This likely led to biased results in the level of trust in the respondents who filled out the questionnaire. The response rate for the return of questionnaires from relatively low respondents was also perceived as affecting the validity of the study results. Further research is recommended that data collection is also backed-up (accompanied) by questionnaires manually. In addition, to provide information deepening and broader exploration of respondents' answers, further research needs to consider questionnaire techniques with open questions to respondents.

\section{REFERENCES}

Ajzen, I. (1991). The theory of planned behavior. Organizational Behavior and Human Decision Processes, 50 (2), 179-211.

Ajzen, I. (2012). The theory of planned behavior, In P. A., Lange, A. W. Kruglanski, \& E. T. Higgins (Eds.). Handbook of theories of social psychology, vol 1, pp 438-459. London, UK.

Alleyne, P., Hudaib, M., \& Haniffa, R. (2015). The moderating role of perceived organisational support in breaking the silence of public accountants. Journal of Business Ethics, 1-19. doi: 10.1007/s10551015-2946-0.

Bagustianto, R., \& Nurkholis. (2015). Faktorfaktor yang memengaruhi minat Pegawai Negeri Sipil (PNS) untuk melakukan tindakan whistleblowing. Prosiding Simposium Nasional Akuntansi XVIII, Medan, 16-19 September.

Banda, F. L. (2012). Pengaruh penalaran moral, sikap, normatif subyektif dan persepsi kontrol perilaku terhadap whistleblowing intention. Tesis: Universitas Gadjah Mada, 2012.

Bobek, D. D., \& Hatfield, R. C. (2003). An investigation of the theory of planned behavior and the role of moral obligation in tax compliance. Behavior Research in
Accounting, 15,13-38.

Buchan, H. F. (2005). Ethical decision making in the public accounting profession: An extension of Ajzen's theory of planned behavior. Journal of Business Ethics, 61 (2), 165-181.

Carpenter, T. D., \& Reimers, J. L. (2005). Unethical and fraudulent financial reporting: applying the theory of planned behavior. Journal of Business Ethics, 60 (2), 115-129.

Daivitri, A. N. (2013). Pengaruh pertimbangan etis dan komponen perilaku terencana pada niat whistleblowing internal dengan locus of control sebagai variabel pemoderasi. Skripsi: Fakultas Ekonomika dan Bisnis Universitas Gadjah Mada, 2013.

Decree of the Minister of Finance Number 149/KMK.09/2011 on Procedures for Management and Follow-up of Violation Reporting (Whistleblowing) and Procedures for Reporting and Publication of The Implementation of Whistleblowing in the Ministry of Finance (Keputusan Menteri Keuangan Nomor 149/KMK.09/2011 tentang Tata Cara Pengelolaan dan Tindak Lanjut Pelaporan Pelanggaran (Whistleblowing) serta Tata Cara Pelaporan dan Publikasi Pelaksanaan Pengelolaan Pelaporan Pelanggaran (Whistleblowing) di Lingkungan Kementerian Keuangan).

Ghazali, I. (2005). Aplikasi Analisis Multivariate Dengan Program SPSS. Edisi Ketiga. Semarang: BP-Universitas Diponegoro.

Ghozali, I. (2006). Structural Equation Modeling metode alternatif dengan Partial Least Square. Edisi 2. Semarang: BP-Universitas Diponegoro.

Hartono, J. (2011). Metodologi Penelitian Bisnis: Salah Kaprah dan Pengalamanpengalaman. Yogyakarta: BPFE.

Hays, J. B. (2013). An investigation of the motivation management accountants to report fraudulent accounting activity: applying The Theory Of Planned Behavior. Dissertation: Nova Southeastern University, 2013.

Hidayat, W., \& Nugroho, A. A. (2010). Studi empiris Theory of Planned Behavior dan pengaruh kewajiban moral pada perilaku ketidakpatuhan pajak wajib pajak orang pribadi. Jurnal Akuntansi dan Keuangan, 12 (2), 82-93.

Jeon, S. H. (2017). Where to report wrong 
doings? Exploring the determinants of internal versus external whistleblowing. International Review of Public Administration, 1-19.

Kumar, M., \& Santoro, D. (2017). A justification of whistleblowing. Philosophy dan Social Criticism, 43(7), 669-684.

Kurtessis, J.N., Eisenberger, R., Ford, M.T., Buffardi, L.C., Stewart, K.A., \& Adis, C.A. (2015). Perceived organizational support: A meta-analytic evaluation of organizational support theory. Journal of Management, 20(10), 1-31.

Latan, H., Ringle, C.M., \& Jabbour, C.J.C. (2016). Whistleblowing intention among public accountants in Indonesia: Testing for the moderation effects. Journal of Business Ethics, 1-16. doi: 10.1007/s10551-0163318-0.

Law Number 13 of 2006 concerning Witness and Victim Protection (Undang-Undang Nomor 31 Tahun 2014 tentang Perlindungan Saksi dan Korban).

Lestari, R., \& Yaya, R. (2017). Whistleblowing dan faktor-faktor yang memengaruhi niat melaksanakannya oleh Aparatur Sipil Negara. Jurnal Akuntansi, 21 (03), 336350.

Nazir, M. 2003. Metodologi Penelitian. Jakarta: Ghalia Indonesia.

Parianti, N.P.I., dkk. (2016). Faktor-faktor yang memengaruhi niat dan perilaku whistleblowing mahasiswa akuntansi. EJurnal Ekonomi dan Bisnis Universitas Udayana.

Park, H. \& Blenkinsopp, J. (2009). Whistleblowing as planned behavior - A survey of South Korean police officers. Journal of Business Ethics, 85 (4), 545-556.

Regulation of the Minister of Finance Number 103/PMK.09/2010 concerning Procedures for Management and Follow-up Reporting at the Ministry of Finance (Peraturan Menteri Keuangan Nomor 103/PMK.09/2010 tentang Tata Cara Pengelolaan dan Tindak Lanjut Pelaporan di Kementerian Keuangan).

Rustiarini, N.W., \& Sunarsih, N.M. (2015). Fraud dan whistleblowing: Pengungkapan kecurangan akuntansi oleh auditor pemerintah. Prosiding Simposium Nasional Akuntansi XVIII.

Sekaran, U. (2006). Research Methods for Business. 4th Edition. Jakarta: Salemba
Empat.

Su, Chin-Chun \& Ni, Feng-Yu. (2013). Budgetary participation and slack on the theory of planned behavior. International Journal of Organizational Innovation, 5 (4), 91-99.

Suharsimi, A. (2006). Prosedur Penelitian Suatu Pendekatan Praktik, Cet.XIII, Jakarta: PT. Rineka Cipta.

Sulistomo, A., \& Prastiwi, A. (2012). Persepsi mahasiswa akuntansi terhadap pengungkapan kecurangan (studi kasus pada mahasiswa akuntansi UGM dan UNDIP). Jurnal Universitas Diponegoro Semarang.

Sweeney, P. (2008). Hotlines helpful for blowing the whistle. Financial Executive. 24 (4), 28 31.

Uddin, N., \& Gillett, P. R. (2002). The effects of moral reasoning and self-monitoring on $\mathrm{CFO}$ intention to report fraudulently on financial statements. Journal of Business Ethics, 40 (1), 15-32.

Yuswono, T. A., Hartijasti, Y. (2018). Employees Whistleblowing Intention in Public Sector: The Role of Perceived Organizational Support as Moderating Variable. Journal of Accounting and Investment, 19(2), 121136. 